

\section{European Commission}

Joint Research Centre

Institute for Prospective Technological Studies

\section{Contact information}

Fernando Hervás Soriano

Address: Edificio Expo. c/ Inca Garcilaso, 3. E-41092 Seville (Spain)

E-mail: jrc-ipts-secretariat@ec.europa.eu

Tel.: +34954488318

Fax: +34954488300

JRC Science Hub

https://ec.europa.eu/jrc

\section{Legal Notice}

This publication is a Technical Report by the Joint Research Centre, the European Commission's in-house science service. It aims to provide evidence-based scientific support to the European policy-making process. The scientific output expressed does not imply a policy position of the European Commission. Neither the European Commission nor any person acting on behalf of the Commission is responsible for the use which might be made of this publication.

All images (c) European Union 2015

JRC98665

ISSN 1831-9408 (online)

Spain: European Commission, Joint Research Centre, 2015

(C) European Union, 2015

Reproduction is authorised provided the source is acknowledged.

Abstract

A basic assumption in the economic literature is the one of diminishing marginal returns to labour. However, theoretical studies on knowledge and labour specialization assume that an increase in the knowledge investment embodied in the human capital of workers raises the marginal product of labour.

In this paper, we propose a structural approach to test the hypothesis of non-diminishing returns to labour for a panel data set of R\&D investing companies, and we explore how the marginal returns to labour vary with their level of knowledge capital $(R \& D)$ intensity.

Our econometric analysis provides a number of results. First, we find that more knowledge intensive firms have nondiminishing returns to labour, while less knowledge intensive companies exhibit diminishing returns. Second, independently from the knowledge capital intensity, returns to labour increase with size. Relatively smaller firms have diminishing returns, while larger companies have non-diminishing to increasing returns to labour. However, we show that more knowledge intensive firms can attain the threshold of non-diminishing returns faster than their counterparts. 


\title{
Profits, R\&D and labour: Breaking the law of diminishing returns to labour*
}

\author{
Sara Amoroso \\ European Commission, Joint Research Centre, Seville, Spain
}

\begin{abstract}
A basic assumption in the economic literature is the one of diminishing marginal returns to labour. However, theoretical studies on knowledge and labour specialization assume that an increase in the knowledge investment embodied in the human capital of workers raises the marginal product of labour.

In this paper, we propose a structural approach to test the hypothesis of nondiminishing returns to labour for a panel data set of $R \& D$ investing companies, and we explore how the marginal returns to labour vary with their level of knowledge capital $(\mathrm{R} \& \mathrm{D})$ intensity.

Our econometric analysis provides a number of results. First, we find that more knowledge intensive firms have non-diminishing returns to labour, while less knowledge intensive companies exhibit diminishing returns. Second, independently from the knowledge capital intensity, returns to labour increase with size. Relatively smaller firms have diminishing returns, while larger companies have nondiminishing to increasing returns to labour. However, we show that more knowledge intensive firms can attain the threshold of non-diminishing returns faster than their counterparts.
\end{abstract}

JEL classification: J24, L10, L25, O30.

Keywords: size, specialization, profitability, profit function.

\footnotetext{
${ }^{*}$ Correspondence to: sara.amoroso@ec.europa.eu. The author wishes to thank Pietro MoncadaPaternò-Castello (JRC) for his constant and valuable support, Fernando Hervás (JRC), Sandro Montresor (University of Enna) and Antonio Vezzani (JRC) for comments on an earlier version of this paper.
} 


\section{Introduction}

A basic proposition of economic theory is that an increase in labour causes, in general, a less than proportionate increase in the amount of output produced. However, "while the part which nature plays in production shows a tendency to diminishing return, the part which man plays shows a tendency to increasing return. The law of increasing return may be worded thus: an increase of labour and capital leads generally to improved organization, which increases the efficiency of the work of labour and capital." (Marshall, 1890). An example of increasing returns to labour is given by the literature on labour specialization and human capital. A more extensive division of labour increases firms' performance, as the returns to the time spent on tasks is usually greater for workers who concentrate on narrower rages of skills. As Rosen (1983) points out, a motor for specialization is the fact that acquiring knowledge involves a fixed cost, independent of its utilization. As a consequence, its economic return increases with the intensity of its use. Moreover, greater investments in knowledge tend to raise the returns from specialization, because workers become more expert on narrower ranges of tasks, further increasing the benefits from investment in knowledge and a firm's performance (Rosen, 1983; Romer, 1987, Becker, 2009).

The empirical literature on the returns to R\&D has primarily built on the Schumpeterian hypothesis that firm size confers major advantages in performing $R \& D$, and ultimately, in achieving productivity gains. As a result of economies of scale, larger

firms are better at appropriating the returns to $R \& D$ and obtain larger profits (Cohen and Levin, 1989). Also, the market power and access to capital markets of large firms may give them access to investment opportunities that are not available to smaller firms (Klepper, 1996).

This literature has devoted more than thirty years analyzing what firm characteristics are at the root of the heterogeneous returns to R\&D investment (Hall et al., 2010. Mohnen and Hall, 2013). The role of labour as productive input, however, has only been used to explain the differences in these returns across different groups of small and large firms. Very little attention has been paid to the returns to labour, using $\mathrm{R} \& \mathrm{D}$ to explore differences in these returns.

In this paper, we fill this gap and test the hypothesis of non-diminishing returns to labour for a set of R\&D investing companies. Theoretical evidence on specialization and human capital suggests that more R\&D intensive firms may have opportunities not only for economies of scale, but also for economies of skill (specialization). Therefore, we postulate that the marginal returns to labour will be non-diminishing for companies 
with a higher level of knowledge capital $(\mathrm{R} \& \mathrm{D})$ intensity.

To do so, we propose a structural approach to retrieve production function parameters using a profit function, exploiting the duality between the production and profit functions (McFadden, 1978; Levin and Milgrom, 2004).

To our knowledge, this hypothesis has not yet been explicitly tested and could provide further insights on the discussion on how investment in human capital specialization could increase firms' returns and ultimately lead to economic growth.

The paper is structured as follows. Section 2 presents the theoretical background on which our proposed empirical framework rests. Section 3 describes the data and the variables selected for the regression analysis. Section 4 presents and discusses the results. Sections 5 concludes.

\section{Theoretical framework}

The relationship between profits and size has been analysed by many strands of theoretical and empirical research.

Studies investigating the link between performance and R\&D investment have focused on methodologies to retrieve and estimate the returns to $R \& D$, controlling for the size of the firm to explain eventual differences in the returns (Acs and Audretsch, 1987, Link and Rees, 1990; Ciftci and Cready, 2011; Bogliacino and Pianta, 2012; Montresor and Vezzani, 2015). These studies have shown that the heterogeneity within industries in $R \& D$ effort and profitability can be largely attributed to the exploitation of economies of scale. In fact, larger firms are better positioned to appropriate the returns to R\&D due to the size and cost spreading advantages of firms (Cohen et al., 1987. Klepper, 1996; Cohen and Klepper, 1996).

In this regard, Adam Smith and later Alfred Marshall pointed out that one of the main advantage of production on a large scare are the "economies of skill". In particular, after introducing the basic relation between the division of labour into skilled versus unskilled workers, Marshall stated that the main advantage of the division of labour is the fact that the substitution of unskilled labour with machinery improvements cheapens and makes more accurate the work of skilled labour, generating increasing returns. Production technologies become more and more complex and create further opportunities for the division of labour into routine tasks, that can be performed by machines following programmed rules, and non-routine tasks for which the rules are not sufficiently well understood to be programmed and executed by a machine Autor et al. 
2003).1 Additionally, he stressed the fact that "the large manufacturer has a much better chance than a small one has, of getting hold of men with exceptional natural abilities, to do the most difficult part of his work, that on which the reputation of his establishment chiefly depends" (Marshall, 1890, Book IV, chapter XI, § 3).

The literature on labour specialization advocates that non-diminishing marginal returns of labour are the result of technology specialization and specialized (or skilled) workforce in the production process. "The productivity of specialists at particular tasks depends on how much knowledge they have. The dependence of specialization on the knowledge available ties the division of labor to economic progress since progress depends on the growth in human capital and technologies." Becker, 2009, Chapter XI, p.300).

Only few studies have analyzed the returns to size. McClelland et al. (1986) explore the theoretical difference between the concepts of returns to size and to scale. They conclude that economies of scale are merely related to the particular production technology and do not require economic efficiency, while economies of size requires the firm to be operating on its input efficiency. Hall and Weiss (1967), using a cross-section of 341 out of 500 largest firms in the US during 1956-62, discovered either a strong positive and increasing or a diminishing relationship of profit rates with firm size, depending on the specification adopted.

Modern research in labour economics is focused on 'people' rather than on firms (Oi and Idson, 1999; Söderbom et al. 2004). This literature has studied the impact of various factors, including firm size, on workers earnings. A common finding is that earnings rise with firm size, because employees at larger firms are more productive and hence require higher wages in a competitive labor market (Oi and Idson, 1999).

Despite the theoretical and empirical evidence on the returns to $R \& D$, little attention has been paid to the returns to labour, considering the opportunities for economies of skill of R\&D intensive firms. Therefore, in this paper, we explore the dependence between labour and profits, and we test the hypothesis that the marginal returns to labour differ across levels of knowledge capital (R\&D) intensity.

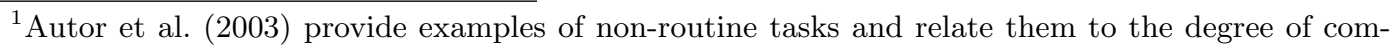
plementarity with computers. In their article, they define analytical and interactive tasks, such as forming and testing hypotheses, medical diagnosis, persuading and selling and management of other, as activities that are strongly complementary to computer technology, and manual tasks such as janitorial services, driving a car through city traffic or deciphering the handwriting, as tasks that are still non-routine, but hardly complemented or assisted by technology.
} 


\subsection{Structural econometric model}

The literature on the returns to $\mathrm{R} \& \mathrm{D}$ had relied on a production function framework, where the output of a firm is related to its stock of $R \& D$ or knowledge capital, along with the other factors of production. ${ }^{2}$ This approach essentially relates (the growth of) partial or total factor productivity to R\&D.

However, the danger with the conventional approaches to productivity (output/input) and efficiency as measures of performance is that they tend to disregard the quantity and quality (price) that is accepted by consumers. A company can be productive and efficient and still making no or even negative profits. Profits and survival are typically taken to be positively associated: low current profits may threaten current survival, while high current profits makes exit from a market less likely. Sutton (2006) changes the perspective on this conventional view, by suggesting that the relationship between profits and survival is mediated by investment in 'flexible capabilities', i.e. investment in know-how that can respond quickly and efficiently to changes in future market conditions.

Therefore, alternatively to a production function, we rely on a profit function to retrieve the returns to labour and other factors of production. The proposed framework can be generalized to retrieve measures of profitability, such as profits per employee. Under the (usual) assumptions of profit-maximizing behaviour, imperfect capital market competition and Cobb-Douglas production technology, the production function of a company can be written as

$$
Q_{i t}=L_{i t}^{\alpha} C_{i t}^{\beta} K_{i t}^{\gamma} e^{\epsilon_{i t}}
$$

where $Q$ is output (in terms of value added), $L$ and $C$ are the traditional labour and physical capital input factors, $K$ is the knowledge capital, $\alpha, \beta$, and $\gamma$ are the elasticities with respect to each of the inputs.

Firms face Dixit-Stiglitz demand curves, where the demanded quantity is a function of the constant elasticity of demand, $\eta$, the industry aggregate price index, $P_{t}$, and total market size, $I_{t}$. The demand is then $Q_{i t}^{D}=P_{t}^{1-\eta} I_{t}\left(P_{i}\right)^{\eta}$, and the market size given by the revenues of $n$ firms in a market, $I_{t}=\sum_{i=1}^{n} P_{i} Q_{i t}^{D}$.

\footnotetext{
${ }^{2}$ See Hall et al. (2010) and Mohnen and Hall (2013) for an extensive overview of the different methodologies used to estimate the returns to R\&D.
} 
Profits, defined as revenues minus costs, are a variable proportion of output $3^{3}$

$$
\Pi_{i t}=\Phi_{j t} Q_{i t}
$$

where, taking the inverse demand function, $\Phi_{j t} \simeq P_{i t}^{D}-v_{t}=\left(P_{t}^{1-\eta} I_{j t}\right)_{j t}^{-1 / \eta}\left(Q_{i}\right)^{1 / \eta}-v_{t}$ accounts for changes in input prices, $v_{t}$ and aggregate market prices and quantity indices, $P_{t}$ and $I_{j t}$.

Substituting $Q_{i t}$ in (2) with (1) and taking logs, we can write the profits as

$$
\pi_{i t}=\phi_{j t}+\alpha l_{i t}+\beta c_{i t}+\gamma k_{i t}+\epsilon_{i t}
$$

where the small-case letters indicate logs. To proxy for market-varying characteristics we use the log of aggregate industry sales.

To account for non-linearity in size $4^{4}$ we re-write $(3)$ as

$$
\pi_{i t}=\phi_{j t}+\alpha_{1} l_{i t}+\alpha_{2} l_{i t}^{2}+\beta c_{i t}+\gamma k_{i t}+\epsilon_{i t}
$$

According to the the law of diminishing marginal returns, the signs of $\alpha_{1}$ and $\alpha_{2}$ should be respectively positive and negative, so that the total product and the marginal product of labour look like in Figure 1. Given the aforementioned theoretical evidence of increasing returns to labour, we test the sign of $\alpha_{2}$. We further investigate whether the sign of $\alpha_{2}$ differs across groups of firms more or less knowledge intensive, given that the presence of economies of skill (economies of division of labour) may be accentuated in $R \& D$ intensive firms. In fact, for this type of firms, R\&D investment often entails substantial fixed costs and the complexity of the underlying science offers considerable scope for labour specialization, which could lead to non-diminishing marginal returns.

When estimating (4), there are several endogeneity issues concerning the collinearity among unobserved firm heterogeneity, input prices and factors of production.5

\footnotetext{
${ }^{3}$ Profits, under the profit-maximizing condition, can be written as $\pi(p)=\max _{x} f(x)-p x$ (where the price of the output is normalized to one). Levin and Milgrom (2004) show that if $f$ is concave, then the production function can be written as the function that minimize prices of the profit function, $f(x)=\min _{p} \pi(p)+p x$. So, for some $\hat{p}$, the profit function can be expressed as

$$
\pi(\hat{p})=f(x)-\hat{p} x .
$$

McFadden (1978) introduced the profit analog of the duality theorem, relating the structural properties of production possibilities to the structural of cost and profit functions. Lau (1976) proposes econometric application of the profit function. In particular, he shows how estimated of production elasticities may be derived given the elasticities of the normalized profit function.

${ }^{4} \mathrm{We}$ also tried a third degree polynomial, but the results were inconsistent across estimation approaches and estimation samples.

${ }^{5}$ Another well-known problem when estimating the contribution of R\&D to output is the 'double-
} 


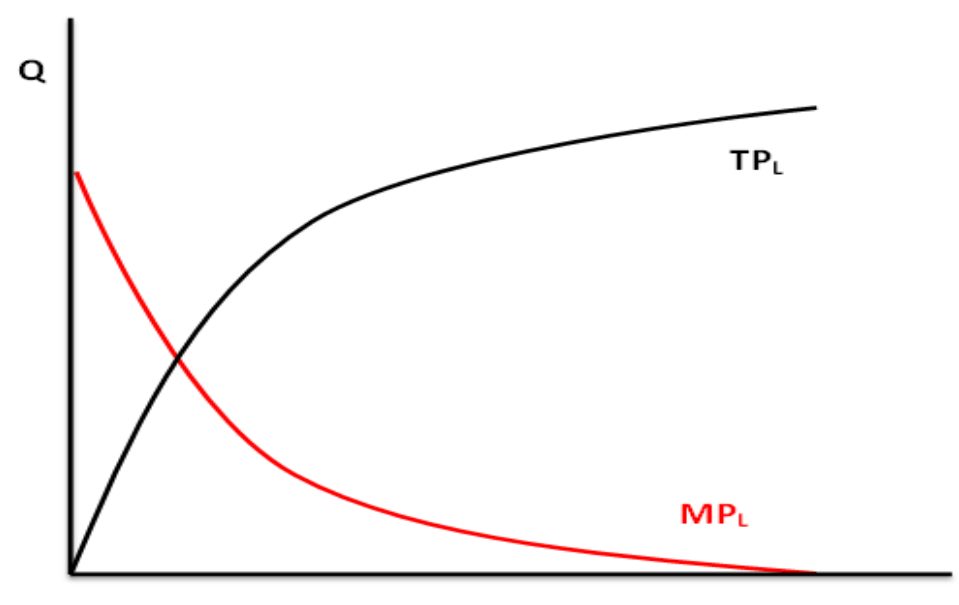

$\mathbf{L}$

Figure 1

To tackle such endogeneity issues, scholars have proposed a number of econometric techniques, ranging from instrumental variables to control function approaches (see Ackerberg et al., 2007). In the next section, we report and discuss the results from a two-step GMM and other econometric approaches used as robustness check. In our specification, having assumed physical capital market imperfections, labour and knowledge capital are endogenous and instrumented by their lagged values.

\section{Data}

We estimate (4) using a panel data set of R\&D intensive companies, coming from the EU Industrial R\&D Investment Scoreboard (http://iri.jrc.ec.europa.eu/) EU R\&D Scoreboard form here onwards. The EU R\&D Scoreboard covers nearly all the more important players in term of R\&D investments in the world (especially in mid-high and high-tech sectors) and accounts for nearly $90 \%$ of the total world R\&D expenditure ${ }^{6}$ A number of studies has used the EU R\&D Scoreboard data to investigate a number

counting' of R\&D (Schankerman, 1981). R\&D investment consists of investment in physical capital, labour and possibly in other factors. These traditional inputs are already included in the production function, and failing to correct the mismeasurement produce a bias in the estimation of output elasticities of both $R \& D$ and labour. If the data do not provide information on the number of R\&D employees and physical R\&D capital that allow to correct for the double-counting, (Mairesse and Hall, 1996, p.5) show that the estimates will not be incorrect, but the measured R\&D coefficient will be an 'excess' elasticity of output to R\&D, rather than a total elasticity.

${ }^{6}$ It refers to the most updated figures by EUROSTAT (EC), where the Business Enterprise Expenditure on R\&D (BERD) financed by the business enterprise sector in 2009 is compared with the overall R\&D investments of the same year coming from the EU R\&D Scoreboard companies. 
of interesting issues (Cincera et al., 2010; García-Manjón and Romero-Merino, 2012, Cincera and Veugelers, 2014; Montresor and Vezzani, 2015; Amoroso et al., 2015). The balanced panel data set contains economic and financial data 7 of the top 2000 world R\&D investors and cover the 2004-2012 period. Data are collected from the companies' published accounts and refer to the ultimate parent company in the case of consolidated groups. Therefore, the country attributed to a given company refers to the country where headquarter is located. Subsidiaries are included when consolidated group accounts of the ultimate parent company are not available. The key variable of the EU $\mathrm{R} \& \mathrm{D}$ Scoreboard is the cash investment in $\mathrm{R} \& \mathrm{D}$ (as from international accounting standards) that the companies funded themselves, excluding those undertaken under contract for customers such as government or other companies. In addition, companies report data on net sales, operating profit, capital expenditure, number of employees and market capitalization. The EU R\&D Scoreboard economic data are nominal and expressed in Euro with all foreign currencies converted at the exchange rate of the yearend closing date. All the economic figures have been deflated using the GDP deflators published by the World Bank, and using 2004 as the reference year. For companies located in the Cayman Islands we applied the World average deflator. In the case of companies based in Taiwan (Chinese Taipei), we used the "Implicit GDP Price Indices" taken from the OECD-MSTI database. By its very nature the EU R\&D Scoreboard sample is somehow biased towards medium-large companies.

Table 1 reports summary statistics of the variables included in the empirical model for the whole estimation sample and by knowledge capital intensity. Knowledge capital intensity, $k$ int., is defined as knowledge capital per euro of physical capital. We use knowledge capital intensity to test the hypothesis that knowledge-intensive firms have non-diminishing returns to labour. Therefore, taking the median as a cutoff value, we split the sample into two: below and above the 50-th percentile of knowledge capital intensity. Market-varying characteristics $\phi$ are proxied by the log of aggregate industry sales.

Additional to physical and knowledge capital, we control for the age of the company. The age of the companies is calculated as the number of years from the foundation date. The foundation date of a company may refer to the historical foundation date of the business, or to the creation of a new business via mergers and acquisitions, or spin-offs (i.e. the divisions of companies become independent businesses). Hence, a firm's age

\footnotetext{
${ }^{7}$ The Scoreboard's approach here is fundamentally different from that of national statistical offices or the OECD when preparing Business Enterprise Expenditure on R\&D (BERD) data, which are specific to a given territory. An extended discussion on the subject could be found in Moncada-Paternò-Castello et al. (2010).
} 
Table 1: Summary statistics for the whole sample and by knowledge capital intensity

\begin{tabular}{lrrrrrrrr}
\hline & OP & $\Delta$ OP & Phys.C. & R\&D C. & Empl. & $\phi$ & Age & $k$ int. \\
\hline mean & 498.01 & 0.08 & 2655.93 & 931.97 & 19.40 & 13.08 & 41.81 & 2.34 \\
sd & 2019.90 & 0.73 & 9240.82 & 3079.27 & 48.38 & 0.73 & 42.24 & 17.81 \\
p25 & 8.49 & -0.14 & 80.45 & 70.50 & 1.14 & 12.76 & 14 & 0.25 \\
p50 & 61.54 & 0.09 & 335.73 & 159.76 & 4.41 & 13.19 & 26 & 0.61 \\
p75 & 261.98 & 0.32 & 1362.33 & 462.63 & 14.82 & 13.56 & 62 & 1.74 \\
min & -27853.40 & -7.18 & 0.05 & 0.04 & 0.00 & 9.63 & 1 & 0.00 \\
max & 49887.63 & 7.94 & $1.75 \mathrm{e}+05$ & $4.44 \mathrm{e}+04$ & 961 & 14.69 & 648 & 1773.95 \\
\hline & & & & & & & & $k-i n t_{01}$ \\
mean & 867.84 & 0.04 & 4712.84 & 720.59 & 27.93 & 13.14 & 56.29 & 0 \\
skewness & 7.60 & -0.50 & 6.11 & 9.52 & 5.45 & -0.64 & 1.80 & \\
mean & 337.25 & 0.10 & 1019.53 & 1072.98 & 15.61 & 13.06 & 36.07 & 1 \\
skewness & 4.45 & 0.07 & 6.59 & 5.68 & 5.94 & -1.08 & 3.53 &
\end{tabular}

Note: All figures are expressed in thousand Euro (and thousand employees). $k$ - int to1 $_{1}$ is a dummy equal 0 if $k$-intensity is below its 50-th percentile, equal to 1 otherwise.

can be reset to zero if it changes its incorporation status or is acquired. There is a large literature on the relationship between firm age and its performance, without any claim of being exhaustive we refer to some recent works to highlight that a general consensus on a positive relationship seems to emerge. Indeed, Cincera and Veugelers (2014), using sample of top world R\&D investing companies, find that young leading innovators gain higher corporate returns from $\mathrm{R} \& \mathrm{D}$, but this holds true only for US companies. Schneider and Veugelers (2010) provide evidence supporting the hypothesis that young innovative companies introduce more radical innovations.

Table 1 shows that all variables are positively skewed (except for the growth of operating profits and the market characteristic $\phi$ ) and displays the means and skewness of the variables across the two samples. Companies that are less knowledge intensive have on average larger operating profits, physical capital and number of employees, and are "older". More knowledge intensive firms have, clearly, larger R\&D capital and higher average profit growth (about 2.5 times higher than less knowledge intensive firms).

\section{Results and discussion}

Table 2 reports the main findings of the econometric analysis of the relationship between firms' profits and labour for R\&D intensive companies. The estimations allow to take 
into account for the likely endogeneity of labour and R\&D capital. The reported Hansen test of overidentification validates at the $5 \%$ level the set of instruments used. Results are organized in three sets of two columns. Each pair of column reports estimations of (3) and (4). The first two columns report estimation results for the whole sample of companies, the second and last pairs of columns display results for firms with knowledge intensity smaller or larger than the median value, respectively.

Results confirm the hypothesis of non-diminishing marginal returns to labour for the sample of biggest world R\&D investors. More specifically, the coefficient measuring the return to square labour is negative but not statistically significant for the whole sample of firms, negative and statistically significant for the set of companies that are less knowledge intensive, and equal to zero for the more knowledge intensive firms. When considering the specification as in equation (3) (without the second degree labour polynomial), output labour elasticities are estimated between 36 and 39\%. When including the quadratic term, the estimated labour elasticities are larger for the whole sample and for the less technological intensive. This is due to the fact that the elasticity of output with respect to labour is not $\alpha$ anymore, but it is $\alpha_{1}+2 \alpha_{2} l$. This means that the percentage change in output for one percent change in labour is smaller as the number of employees increases. Taking the average value of $l$ of the less knowledge capital intensive firms, their profit elasticity of labour is equal to $37 \%$. Figure 2 displays the estimated total product of labour (TPL) for more and less knowledge intensive firms, and shows that firms that are less knowledge capital intensive exhibit diminishing marginal returns to labour, obeying the law depicted in Figure 1, while more knowledge intensive firms do not.

The estimated elasticities of knowledge and physical capital are in line with the results generally reported in the augmented production function literature (see Hall et al., 2010). The profit elasticities of physical capital are larger then the elasticity of knowledge capital for the whole sample and for the sample of less knowledge intensive firms. The situation is reversed for firms that have a knowledge intensity above the median (physical and knowledge capital elasticities of 0.255 and 0.343 , respectively, although the difference is not statistically significant). Similarly to previous studies that have examined the returns to $R \& D$ using the same data but different methodologies, we find that the R\&D capital elasticity is larger for more technology intensive firms (Kumbhakar et al., 2012; Cincera and Veugelers, 2014; Montresor and Vezzani, 2015).

As for the results related to firm age, in line with Coad and Rao (2010) who find a negative effect of age on profitability, we find a consistent negative relationship between age of the firm and profits, suggesting that older companies have lower corporate results. 
Table 2: Profit function estimation - IV regression

\begin{tabular}{lcccccc}
\hline & \multicolumn{2}{c}{ whole sample } & \multicolumn{2}{c}{ k-intensity $=0$} & \multicolumn{2}{c}{ k-intensity $=1$} \\
\hline$l$ & $0.383^{* * *}$ & $0.484^{* * *}$ & $0.365^{* * *}$ & $0.888^{* * *}$ & $0.393^{* * *}$ & $0.392^{*}$ \\
& $(0.036)$ & $(0.175)$ & $(0.045)$ & $(0.315)$ & $(0.045)$ & $(0.216)$ \\
$l^{2}$ & & -0.006 & & $-0.028^{*}$ & & -0.000 \\
& & $(0.009)$ & & $(0.016)$ & & $(0.012)$ \\
$k$ & $0.223^{* * *}$ & $0.222^{* * *}$ & 0.057 & 0.055 & $0.344^{* * *}$ & $0.343^{* * *}$ \\
& $(0.027)$ & $(0.028)$ & $(0.035)$ & $(0.036)$ & $(0.062)$ & $(0.064)$ \\
$c$ & $0.357^{* * *}$ & $0.364^{* * *}$ & $0.545^{* * *}$ & $0.568^{* * *}$ & $0.254^{* * *}$ & $0.255^{* * *}$ \\
& $(0.037)$ & $(0.037)$ & $(0.051)$ & $(0.050)$ & $(0.065)$ & $(0.066)$ \\
age & $-0.086^{* * *}$ & $-0.088^{* * *}$ & $-0.078^{* *}$ & $-0.091^{* *}$ & $-0.091^{* *}$ & $-0.090^{* *}$ \\
& $(0.028)$ & $(0.028)$ & $(0.038)$ & $(0.038)$ & $(0.042)$ & $(0.042)$ \\
$\phi$ & 0.114 & 0.128 & 0.116 & 0.140 & 0.107 & 0.104 \\
& $(0.093)$ & $(0.093)$ & $(0.099)$ & $(0.098)$ & $(0.211)$ & $(0.211)$ \\
\hline Observations & 7,891 & 7,891 & 4,113 & 4,113 & 3,778 & 3,778 \\
R-squared & 0.725 & 0.725 & 0.714 & 0.713 & 0.712 & 0.712 \\
Adj. R2 & 0.724 & 0.724 & 0.712 & 0.711 & 0.710 & 0.710 \\
Rmse & 0.943 & 0.943 & 0.853 & 0.856 & 1.001 & 1.001 \\
Hansen test & 0.000 & 0.000 & 0.000 & 0.000 & 0.000 & 0.000 \\
\hline
\end{tabular}

Robust standard errors in parentheses. Sector and year dummies included $* * * \mathrm{p}<0.01,{ }^{* *} \mathrm{p}<0.05,{ }^{*} \mathrm{p}<0.1$

As discussed in Section 3, the age of the Scoreboard companies identifies the number of years from the foundation year, which can be reset to zero in case of ownership restructuring. Therefore, in this case the group of 'younger' firms not only includes firms truly founded recently, but also denotes a group of firms that are more dynamic, as they undergo changes in ownership structure to lift/rejuvenate or change corporate strategy and business focus (Moncada-Paternò-Castello, 2015). Several studies have analysed the impact of ownership structure on firm performance and often point at the evidence that changes in performance are positively associated with changes in ownership (Cole and Mehran, 1998).

\subsection{Robustness analysis}

Tables 3 , 4 and 5 compare the estimated input factors elasticities estimated from a within estimation (FE), a generalized least square (GLS) allowing for panels autocorrelation and heteroskedasticity, and least absolute deviation (median) regression. The within estimator yields smaller coefficients of labour and physical capital, and larger returns to knowledge capital. The coefficient measuring the quadratic impact of labour on profits is negative for the whole sample, but no statistical difference is found among the two groups of firms. Results from the GLS estimation in Table 4 are similar to those 


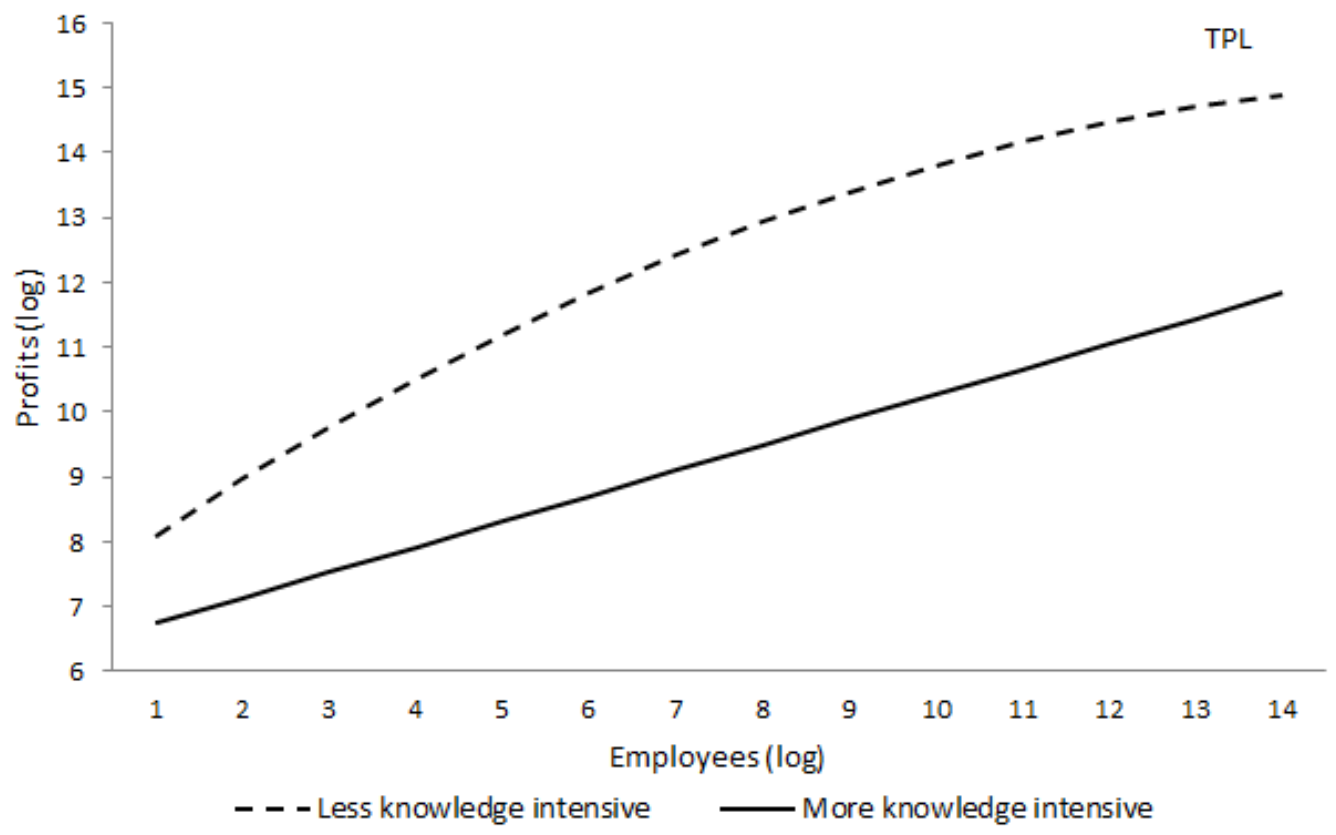

Figure 2

obtained with instrumental variables, with evidence of diminishing returns to labour only for the less knowledge intensive companies. When turning to median regressions, Table 5, the profit function parameter are in concordance with IV and GLS estimates, and there is no evidence of diminishing returns to labour in any of the samples. Figure 4 displays the estimated coefficient of the quadratic term in labour, $\alpha_{2}$, from the quantile regression and the $95 \%$ confidence interval. While for more knowledge intensive firms marginal returns are decreasing till approximately the 30th percentile, for the other sample, marginal returns to labour continue to be decreasing until the 40th percentile. In other words, less knowledge intensive firms have to be able to generate a lot more profits than their counterparts to achieve non-diminishing marginal returns to their workers. Additionally, more knowledge intensive companies have a higher operating profit growth rate. Therefore, one can conclude that R\&D capital investment may help firms to reach the threshold of non-diminishing/increasing returns to labour faster than if they did not invest as much in R\&D.

Figure 4 shows that a large part of the story behind the marginal returns to labour depends on the level of operating profits.

Figure 3 shows that firms with larger profits are also larger in size. Therefore, the 


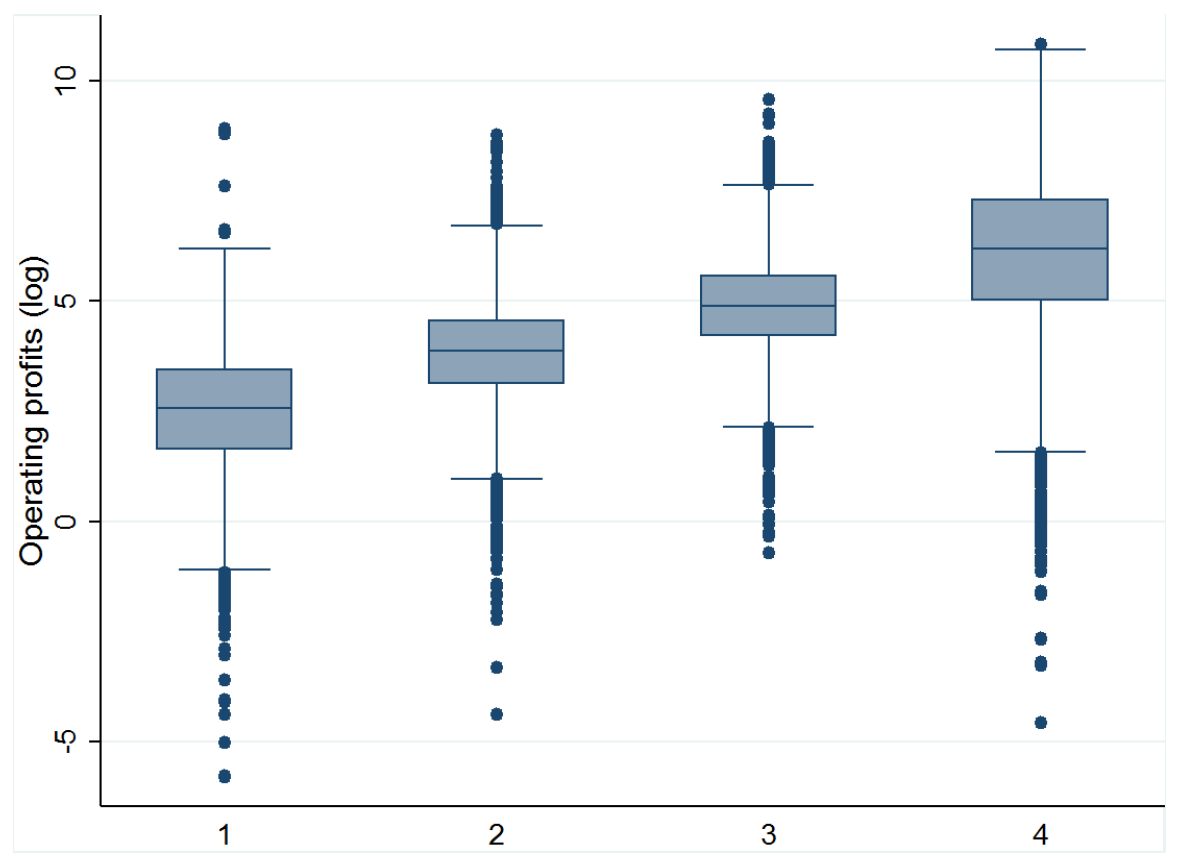

Figure 3: Log of profits by employment quartiles

returns to labour increase with firm size. This is in line with Marshall's prediction of higher economies of skill for larger manufacturers: an increase in team size results in greater specialization and division of labor, which raises both the marginal product of effort and expected output per worker (Becker and Murphy, 1992).

A second interpretation to these results is that larger corporations are likely to operate internationally as they have more financial resources and better international experience. In an era of global value chains, where firms geographically separate different production stages across the world to exploit differences in production costs, the complex and tightly coordinated production systems call for an international inter-firm divisions of labour. In addition, the advances in information and communication technology (ICT) have reduced the difficulty of coordinating international processes and have shifted the organization of work toward flexible and self-managed team structure, job rotation and worker multitasking (Bresnahan et al., 2002, Bloom and Van Reenen, 2011). A deeper analysis on the degree of internationalization (and firms organizational choices, such as offshoring and outsourcing) and its impact of the returns to labour is needed and left for future investigation. 
Table 3: FE estimation

\begin{tabular}{lcccccc}
\hline & \multicolumn{2}{c}{ whole sample } & \multicolumn{2}{c}{ k-intensity $=0$} & \multicolumn{2}{c}{$\mathrm{k}$-intensity=1 } \\
\hline$l$ & $0.276^{* * *}$ & $0.618^{* * *}$ & $0.209^{* * *}$ & 0.041 & $0.296^{* * *}$ & $0.434^{* *}$ \\
& $(0.027)$ & $(0.124)$ & $(0.031)$ & $(0.193)$ & $(0.050)$ & $(0.195)$ \\
& & $-0.020^{* * *}$ & & 0.010 & & -0.009 \\
& & $(0.007)$ & & $(0.011)$ & & $(0.012)$ \\
$k$ & $0.344^{* * *}$ & $0.339^{* * *}$ & $0.299^{* * *}$ & $0.296^{* * *}$ & $0.366^{* * *}$ & $0.358^{* * *}$ \\
& $(0.038)$ & $(0.038)$ & $(0.044)$ & $(0.044)$ & $(0.075)$ & $(0.076)$ \\
& $0.301^{* * *}$ & $0.293^{* * *}$ & $0.119^{*}$ & $0.116^{*}$ & $0.348^{* * *}$ & $0.345^{* * *}$ \\
& $(0.041)$ & $(0.041)$ & $(0.066)$ & $(0.066)$ & $(0.065)$ & $(0.065)$ \\
$\phi$ & $0.857^{* * *}$ & $0.876^{* * *}$ & $0.611^{* * *}$ & $0.600^{* * *}$ & $1.411^{* * *}$ & $1.421^{* * *}$ \\
& $(0.113)$ & $(0.113)$ & $(0.122)$ & $(0.122)$ & $(0.241)$ & $(0.241)$ \\
Constant & $-16.640^{* * *}$ & $-18.117^{* * *}$ & $-9.580^{* * *}$ & $-8.646^{* * *}$ & $-24.982^{* * *}$ & $-25.516^{* * *}$ \\
& $(1.479)$ & $(1.568)$ & $(1.625)$ & $(1.940)$ & $(3.122)$ & $(3.206)$ \\
\hline Observations & 9,116 & 9,116 & 4,771 & 4,771 & 4,345 & 4,345 \\
R-squared & 0.138 & 0.139 & 0.101 & 0.102 & 0.163 & 0.163 \\
N. panels & 1,215 & 1,215 & 675 & 675 & 676 & 676 \\
R2 & 0.547 & 0.533 & 0.399 & 0.407 & 0.500 & 0.493 \\
Rmse & 0.627 & 0.626 & 0.556 & 0.556 & 0.680 & 0.680 \\
\hline
\end{tabular}

Standard errors in parentheses. Year effects included. $* * * \mathrm{p}<0.01,{ }^{* *} \mathrm{p}<0.05,{ }^{*} \mathrm{p}<0.1$

Table 4: GLS estimation (heteroscedastic and serially correlated panels)

\begin{tabular}{lcccccc}
\hline & \multicolumn{2}{c}{ whole sample } & \multicolumn{2}{c}{$\mathrm{k}$-intensity $=0$} & \multicolumn{2}{c}{$\mathrm{k}$-intensity=1 } \\
\hline$l$ & $0.323^{* * *}$ & $0.325^{* * *}$ & $0.322^{* * *}$ & $0.488^{* * *}$ & $0.323^{* * *}$ & $0.284^{* * *}$ \\
& $(0.012)$ & $(0.062)$ & $\mathrm{d}(0.016)$ & $(0.099)$ & $(0.020)$ & $(0.081)$ \\
$l^{2}$ & & -0.000 & & $-0.009^{*}$ & & 0.002 \\
& & $(0.003)$ & & $(0.005)$ & & $(0.005)$ \\
& $0.249^{* * *}$ & $0.251^{* * *}$ & $0.099^{* * *}$ & $0.103^{* * *}$ & $0.444^{* * *}$ & $0.445^{* * *}$ \\
& $(0.011)$ & $(0.012)$ & $(0.015)$ & $(0.015)$ & $(0.027)$ & $(0.028)$ \\
& $0.354^{* * *}$ & $0.354^{* * *}$ & $0.499^{* * *}$ & $0.501^{* * *}$ & $0.173^{* * *}$ & $0.180^{* * *}$ \\
& $(0.013)$ & $(0.013)$ & $(0.019)$ & $(0.019)$ & $(0.026)$ & $(0.027)$ \\
$\phi$ & $0.451^{* * *}$ & $0.473^{* * *}$ & $0.313^{* * *}$ & $0.315^{* * *}$ & $0.852^{* * *}$ & $0.897^{* * *}$ \\
& $(0.041)$ & $(0.042)$ & $(0.044)$ & $(0.044)$ & $(0.107)$ & $(0.111)$ \\
age & $-0.064^{* * *}$ & $-0.063^{* * *}$ & $-0.079^{* * *}$ & $-0.081^{* * *}$ & $-0.069^{* * *}$ & $-0.063^{* * *}$ \\
& $(0.013)$ & $(0.013)$ & $(0.018)$ & $(0.018)$ & $(0.019)$ & $(0.020)$ \\
Constant & $-10.963^{* * *}$ & $-11.273^{* * *}$ & $-9.267^{* * *}$ & $-10.127^{* * *}$ & $-16.273^{* * *}$ & $-16.789^{* * *}$ \\
& $(0.535)$ & $(0.620)$ & $(0.571)$ & $(0.755)$ & $(1.370)$ & $(1.484)$ \\
\hline Observations & 8,049 & 8,049 & 4,140 & 4,140 & 3,841 & 3,841 \\
N. panels & 1,177 & 1,177 & 615 & 615 & 631 & 631 \\
Wald test & 23405 & 22178 & 14239 & 14190 & 26339 & 12605 \\
Rho & 0.677 & 0.694 & 0.666 & 0.667 & 0.686 & 0.712 \\
\hline
\end{tabular}

Standard errors in parentheses. Sector and year effects included.

*** $\mathrm{p}<0.01,{ }^{* *} \mathrm{p}<0.05,{ }^{*} \mathrm{p}<0.1$ 

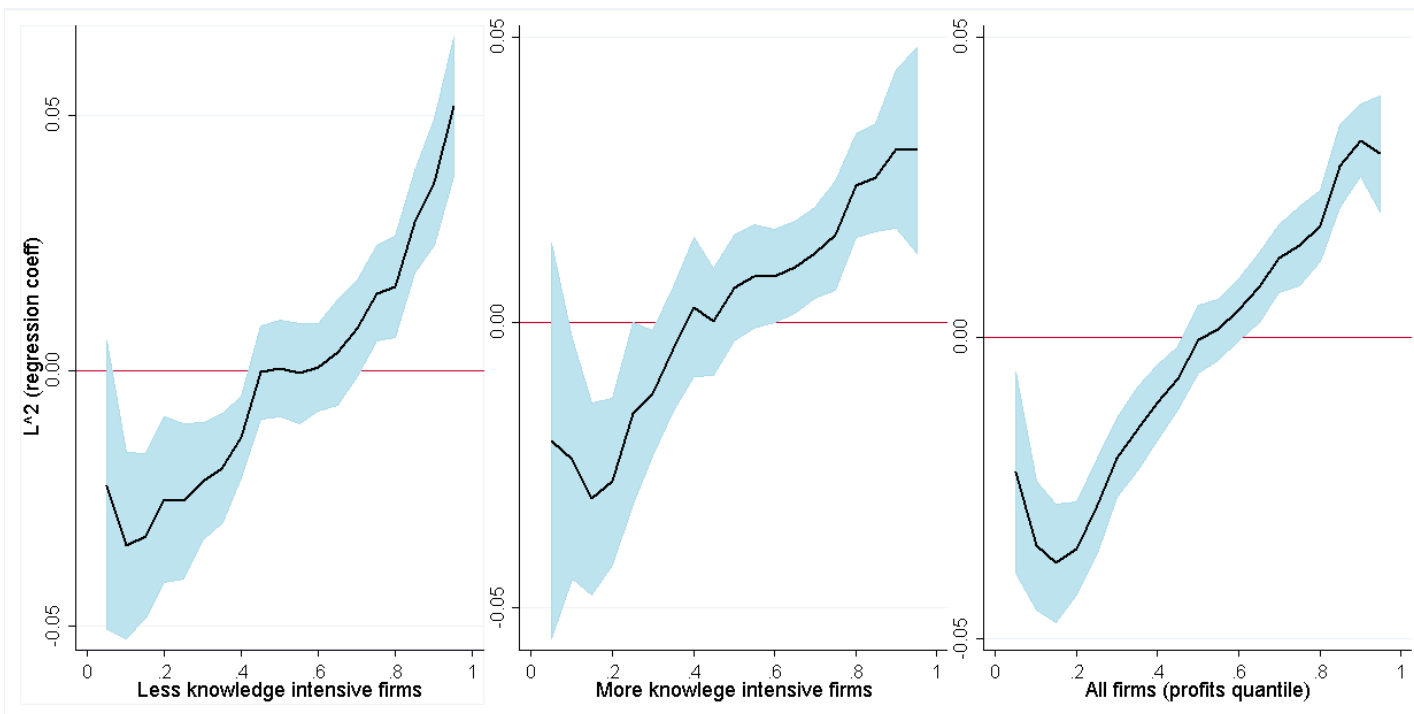

Figure 4: Distribution of $l^{2}$ coefficient from quantile regression - all firms

Table 5: Least absolute deviation estimation

\begin{tabular}{lcccccc}
\hline & $(1)$ & $(2)$ & \multicolumn{2}{c}{$(3)$} & $(4)$ & \multicolumn{2}{c}{$(5)$} & $(6)$ \\
& \multicolumn{2}{c}{ whole sample } & \multicolumn{2}{c}{ k-intensity=0 } & \multicolumn{2}{c}{ k-intensity=1 } \\
\hline$l$ & $0.343^{* * *}$ & $0.348^{* * *}$ & $0.322^{* * *}$ & $0.314^{* * *}$ & $0.356^{* * *}$ & $0.468^{* * *}$ \\
& $(0.012)$ & $(0.074)$ & $(0.015)$ & $(0.110)$ & $(0.017)$ & $(0.105)$ \\
$l^{2}$ & & -0.000 & & 0.000 & & 0.005 \\
& & $(0.004)$ & & $(0.006)$ & & $(0.006)$ \\
$k$ & $0.249^{* * *}$ & $0.249^{* * *}$ & $0.065^{* * *}$ & $0.065^{* * *}$ & $0.419^{* * *}$ & $0.422^{* * *}$ \\
& $(0.010)$ & $(0.011)$ & $(0.016)$ & $(0.016)$ & $(0.025)$ & $(0.026)$ \\
$c$ & $0.376^{* * *}$ & $0.377^{* * *}$ & $0.562^{* * *}$ & $0.562^{* * *}$ & $0.236^{* * *}$ & $0.240^{* * *}$ \\
& $(0.012)$ & $(0.013)$ & $(0.018)$ & $(0.018)$ & $(0.026)$ & $(0.027)$ \\
$\phi$ & $0.093^{* *}$ & $0.094^{* *}$ & 0.077 & 0.076 & 0.028 & 0.049 \\
& $(0.046)$ & $(0.046)$ & $(0.049)$ & $(0.049)$ & $(0.100)$ & $(0.106)$ \\
age & $-0.076^{* * *}$ & $-0.076^{* * *}$ & $-0.089^{* * *}$ & $-0.088^{* * *}$ & $-0.054^{* * *}$ & $-0.054^{* * *}$ \\
& $(0.013)$ & $(0.013)$ & $(0.016)$ & $(0.016)$ & $(0.018)$ & $(0.017)$ \\
Constant & $-6.689^{* * *}$ & $-6.727^{* * *}$ & $-6.400^{* * *}$ & $-6.352^{* * *}$ & $-6.531^{* * *}$ & $-7.296^{* * *}$ \\
& $(0.574)$ & $(0.672)$ & $(0.625)$ & $(0.838)$ & $(1.241)$ & $(1.410)$ \\
\hline Observations & 9,116 & 9,116 & 4,771 & 4,771 & 4,345 & 4,345 \\
Pseudo R2 & 0.523 & 0.523 & 0.509 & 0.509 & 0.523 & 0.523 \\
\hline
\end{tabular}

Robust standard errors in parentheses. Sector and year effects included. *** $\mathrm{p}<0.01,{ }^{* *} \mathrm{p}<0.05,{ }^{*} \mathrm{p}<0.1$ 


\section{Conclusions}

A basic assumption in the economic literature is the one of diminishing marginal returns to labour, where an increase in a labour would lead in a less the proportionate increase in output. One of the exceptions to the law of diminishing returns is advanced by theories on knowledge and labour specialization (Romer, 1987; Rosen, 1983; Becker, 2009), where it is assumed that an increase in the knowledge investment embodied in the human capital of workers raises the marginal product of labour.

With this hypothesis in mind, we contribute to the applied economic literature by testing the evidence of non-diminishing returns to labour in knowledge intensive companies. To our knowledge, this hypothesis has not yet been explicitly tested and could provide further insights on the discussion on how 'on-the-job' training and other kinds of investment in human capital (Becker, 1962) could increase firms' returns and ultimately lead to economic growth.

We investigated the marginal returns to labour of a panel data set of the top world R\&D investors (EU Industrial R\&D Investment Scoreboard). We divided the estimation sample by knowledge capital intensity (R\&D-physical capital ratio) level to explore differences in the marginal returns to labour across sub-samples. Additionally, we proposed a novel structural approach to the estimation of production functions parameters that relies on profit functions.

We estimated and compared the regression coefficients of the profit functions across a number of econometric approaches. Results show that more knowledge intensive firms have non-diminishing returns to labour, while less knowledge intensive companies exhibit diminishing returns. Moreover, results from a quantile regression analysis provide further inside on the relationship between size and marginal returns. On the one hand, returns to labour increase with profits, which are correlated with size. The increase in size may lead to greater specialization and to an international division of labour. Thanks to the advances in ICT, coordination of international organizations has shifted the new division of labour toward a more flexible and multi-tasking team structure, which raises both marginal product of workers' effort and their productivity. On the other hand, less knowledge intensive firms have to be able to grow more than their counterparts to achieve non-diminishing marginal returns to their workforce. However, the average profit growth of more knowledge intensive group of firms is almost three times larger than the less knowledge intensive one, thus investing in knowledge capital will allow firms to grow faster and achieve non-diminishing gains from labour sooner. 


\section{References}

Ackerberg, D., Benkard, C. L., Berry, S., and Pakes, A. (2007). Econometric tools for analyzing market outcomes. Handbook of econometrics, 6:4171-4276.

Acs, Z. J. and Audretsch, D. B. (1987). Innovation, Market Structure, and Firm Size. The Review of Economics and Statistics, 69(4):567-74.

Amoroso, S., Moncada-Paternò-Castello, P., and Vezzani, A. (2015). R\&D profitability: the role of risk and Knightian uncertainty. Small Business Economics, forthcoming.

Autor, D. H., Levy, F., and Murnane, R. J. (2003). The Skill Content Of Recent Technological Change: An Empirical Exploration. The Quarterly Journal of Economics, 118(4):1279-1333.

Becker, G. S. (1962). Investment in human capital: A theoretical analysis. Journal of Political Economy, 70(5):9-49.

Becker, G. S. (2009). Human capital: A theoretical and empirical analysis, with special reference to education. University of Chicago Press.

Becker, G. S. and Murphy, K. M. (1992). The division of labor, coordination costs, and knowledge. The Quarterly Journal of Economics, 107(4):1137-1160.

Bloom, N. and Van Reenen, J. (2011). Human resource management and productivity. Handbook of labor economics, 4:1697-1767.

Bogliacino, F. and Pianta, M. (2012). Profits, R\&D, and innovationa model and a test. Industrial and Corporate Change, page dts028.

Bresnahan, T. F., Brynjolfsson, E., and Hitt, L. M. (2002). Information technology, workplace organization, and the demand for skilled labor: Firm-level evidence. The Quarterly Journal of Economics, 117(1):339-376.

Ciftci, M. and Cready, W. M. (2011). Scale effects of R\&D as reflected in earnings and returns. Journal of Accounting and Economics, 52(1):62-80.

Cincera, M., Ravet, J., et al. (2010). Financing constraints and R\&D investments of large corporations in Europe and the USA. Science and Public Policy, 37(6):455.

Cincera, M. and Veugelers, R. (2014). Differences in the rates of return to R\&D for European and US young leading R\&D firms. Research Policy, 43(8):1413 - 1421. 
Coad, A. and Rao, R. (2010). Firm growth and R\&D expenditure. Economics of Innovation and New Technology, 19(2):127-145.

Cohen, W. M. and Klepper, S. (1996). A Reprise of Size and R \& D. The Economic Journal, 106(437):925-951.

Cohen, W. M. and Levin, R. C. (1989). Empirical studies of innovation and market structure. In Schmalensee, R. and Willig, R., editors, Handbook of Industrial Organization, volume 2, chapter 18, pages 1059-1107. Elsevier, 1 edition.

Cohen, W. M., Levin, R. C., and Mowery, D. C. (1987). Firm size and R\&D intensity: A re-examination. Technical report, National Bureau of Economic Research.

Cole, R. A. and Mehran, H. (1998). The effect of changes in ownership structure on performance: Evidence from the thrift industry. Journal of Financial Economics, $50(3): 291-317$.

García-Manjón, J. V. and Romero-Merino, M. E. (2012). Research, development, and firm growth. Empirical evidence from European top R\&D spending firms. Research Policy, 41(6):1084-1092.

Hall, B. H., Mairesse, J., and Mohnen, P. (2010). Measuring the Returns to R\&D. Working Paper 15622, National Bureau of Economic Research.

Hall, M. and Weiss, L. (1967). Firm size and profitability. The Review of Economics and Statistics, pages 319-331.

Klepper, S. (1996). Entry, exit, growth, and innovation over the product life cycle. The American Economic Review, 86(3):562-583.

Kumbhakar, S., Ortega-Argils, R., Potters, L., Vivarelli, M., and Voigt, P. (2012). Corporate R\&D and firm efficiency: evidence from Europes top R\&D investors. Journal of Productivity Analysis, 37(2):125-140.

Lau, L. (1976). Applications of Profit Functions. Center for Research in Economic Growth, Stanford University.

Levin, J. and Milgrom, P. (2004). Producer Theory. http://web.stanford.edu/ jdlevin/Econ\%20202/Producer

Link, A. and Rees, J. (1990). Firm size, university based research, and the returns to R\&D. Small Business Economics, 2(1):25-31. 
Mairesse, J. and Hall, B. H. (1996). Estimating the productivity of research and development: an exploration of GMM methods using data on French \& United States manufacturing firms. Technical report, National Bureau of Economic Research.

Marshall, A. (1890). The Principles of Economics. McMaster University Archive for the History of Economic Thought.

McClelland, J. W., Wetzstein, M. E., and Musser, W. N. (1986). Returns to scale and size in agricultural economics. Western Journal of Agricultural Economics, pages $129-133$.

McFadden, D. (1978). Cost, Revenue, and Profit Functions. In Fuss, M. and McFadden, D., editors, Production Economics: A Dual Approach to Theory and Applications, volume 1 of Histoy of Economic Thought Chapters, chapter 1. McMaster University Archive for the History of Economic Thought.

Mohnen, P. and Hall, B. H. (2013). Innovation and productivity: an update. Eurasian Business Review, 3(1):47-65.

Moncada-Paternò-Castello, P. (2015). Sector dynamics and firms demographics of top EU R\&D investors in the global economy. JRC-IPTS Working Papers on Corporate R\&D and Innovation (foreseen publication for 2015/2016), Institute of Prospective Technological Studies, Joint Research Centre.

Moncada-Paternò-Castello, P., Ciupagea, C., Smith, K., and T A. (2010). Does Europe perform too little corporate R\&D? A comparison of EU and non-EU corporate R\&D performance . Research Policy, 39(4):523 - 536. Special Section on Innovation and Sustainability Transitions.

Montresor, S. and Vezzani, A. (2015). The production function of top R\&D investors: Accounting for size and sector heterogeneity with quantile estimations. Research Policy, 44(2):381 - 393 .

Oi, W. Y. and Idson, T. L. (1999). Workers Are More Productive in Large Firms. American Economic Review, 89(2):104-108.

Romer, P. M. (1987). Growth based on increasing returns due to specialization. The American Economic Review, 77(2):56-62.

Rosen, S. (1983). Specialization and human capital. Journal of Labor Economics, pages $43-49$. 
Schankerman, M. (1981). The Effects of Double-Counting and Expensing on the Measured Returns to R\&D. The Review of Economics and Statistics, 63(3):454-458.

Schneider, C. and Veugelers, R. (2010). On young highly innovative companies: why they matter and how (not) to policy support them. Industrial and Corporate Change, 19(4):969-1007.

Söderbom, M., Teal, F., and Wambugu, A. (2004). Does firm size really affect earnings? Development and Comp Systems 0409011, EconWPA.

Sutton, J. (2006). Flexibility, profitability and survival in an (objective) model of knightian uncertainty. Technical report, Working paper, London School of Economics. 
Europe Direct is a service to help you find answers to your questions about the European Union Freephone number $\left(^{*}\right)$ : 0080067891011

${ }^{*}$ ) Certain mobile telephone operators do not allow access to 00800 numbers or these calls may be billed.

A great deal of additional information on the European Union is available on the Internet.

It can be accessed through the Europa server http://europa.eu.

How to obtain EU publications

Our publications are available from EU Bookshop (http://bookshop.europa.eu), where you can place an order with the sales agent of your choice.

The Publications Office has a worldwide network of sales agents.

You can obtain their contact details by sending a fax to (352) 29 29-42758.

European Commission

Joint Research Centre - Institute for Prospective Technological Studies

Title: Profits, R\&D and labour: Breaking the law of diminishing returns to labour

Authors: Sara Amoroso

Spain: European Commission, Joint Research Centre

2015 - 20 pp. - 21.0 x $29.7 \mathrm{~cm}$

EUR - Scientific and Technical Research series - ISSN 1831-9408 (online) 
JRC Mission

As the Commission's in-house science service, the Joint Research Centre's mission is to provide EU policies with independent, evidence-based scientific and technical support throughout the whole policy cycle.

Working in close cooperation with policy Directorates-General, the JRC addresses key societal challenges while stimulating innovation through developing new methods, tools and standards, and sharing its know-how with the Member States, the scientific community and international partners.

Serving society

Stimulating innovation Supporting legislation 